\title{
MUSICAL ART OF THE GALICIAN-VOLYNIAN PRINCIPALITY
}

\section{Kindratiuk B. D.}

The essays are an unprecedented collection of systematized materials on musical art of Galician-Volhynian Principality. The music of this period is its significant but uninvestigated historic stage, which contributed to the development of Ukrainian music after the collapse of Kyiv state. Folk art, instrumental culture, music in princes' and towns' everyday life, church chant, chiming art are analysed.

\section{INTRODUCTION}

The musical art of the Galician-Volhynian Principality is a multifaceted complex of phenomena. Among the rich and original cultural heritage of this state, the Galician-Volhynian chronicle with fragments of calendar-based musical and poetic works has a special role. From it, we also learn about the Polovtsian hudets (prophetic singer) Or, who was in the service of the Kyivan Prince, the Przemyślian «словутний пъвець» (famous singer) Mytusa, the performance of songs of praise, bells and bell-ringing. Epics were significantly developed in the Galician lands and Volhynia. The spread of the Christian rite has strengthened the significance of the church service.

A close connection to the heritage of the Kyivan state was a part of the art of this area. The development of culture in the Galician-Volhynian Principality facilitated the consolidation of its historical traditions, which were captured in architecture, painting, chronicles, literature, and language. The information about the original monumental stone architecture of Galician-Volhynian Rus, its decorative sculpture, fresco painting, icon painting, book miniature, works of applied and jewelry art, etc. has already been systematized. Based on the characterized findings, several generations of researchers of Galician history and culture substantiated a special place of art of the Galician-Volhynian state in the Ukrainian spirituality as well as briefly described the genesis and formation of its musical branch ${ }^{1}$.

However, even today, the textbooks do not always characterize separately the achievements of music on the territory of Galician-Volhynian Rus in the Art section, in particular its further development in the second half of the $13^{\text {th }}$ - first half of the $14^{\text {th }}$ century. This prompted the author to write the work proposed to the Reader. Modern achievements of archeology, anthropology, ethnography, history, linguistics, art history and other sciences supplemented

\footnotetext{
${ }^{1}$ Б. Кіндратюк. Нариси музичного мистеитва Галицько-Волинського князівства / [ред. і авт. переднього слова Ю. Ясіновський]. Івано-Франківськ - Львів, 2001. С. 10-11. 
by chronicles help to concretize the concept of musical culture of Volhynia and Galicia of the Princely era, the important role of art in everyday life in those days. Today, it is possible to highlight the evolution of music as a component of the genesis and formation of Ukrainian culture in this area. This will help to better describe the music of the Galician-Volhynian Principality as a significant stage in the history of Ukrainian art, an important and one of the main components of Ukrainian studies as a compilation of intellectual knowledge about Ukraine and its people.

\section{The preconditions for the development of the musical art of the Galician-Volhynian state. Features of folk songs}

The key to the development of music in the Galician lands and Volhynia was the formation of art on a solid centuries-old basis, as evidenced by numerous archaeological finds. Ancient cultures have succeeded each other for thousands of years. Since the entry of Volhynia, Podkarpacia, Naddnistrianshchyna, Przemyśl Land and Cherven Grods into the united Kyiv state, cultural life has become a united process, fell back on traditions formed during the previous period. After the separation of several principalities from Kyivan Rus, a new political and cultural period of Ukraine's development began. The first reason that led to a change in the structure of the Kyivan state was the further ethnic development of the lands, the development of the division of nationalities in its various parts, the emergence of new economic as well as military and political centers, and so on. In the south-western region of Ruthenian Ukraine in the $9^{\text {th }}-12^{\text {th }}$ centuries, the population continues to grow rapidly, and the population density of the territory increases. Agriculture, salt production, including for export, various crafts, trade and cultural ties are further developed. Historians have concluded that in the $12^{\text {th }}$ century, a new strong Ukrainian state called the Galician-Volhynian Principality was formed here. It was established by Roman Mstyslavych († 1205), who united the Principalities of Volhynia and Galicia in 1199. The most prominent ruler of this state was King Danylo Romanovych (1201-1264). It covered most of the lands of Kyivan Rus and continued its state and cultural tradition until 1340, when the Romanovych dynasty ended with the death of the GalicianVolhynian ruler Yuri Boleslav II (its annexation by the Polish conquerors began in 1340 and was complete in 1387$)^{2}$.

The significance of this region in the history of Ukraine lies in the fact that on Ukrainian territory, Kyivan traditions continue in Volhynia, and even more so in Galicia. It became a rich and brilliant part of Kyivan Rus for two centuries, from the second half of the $12^{\text {th }}$ century. Even after the MongolTatar invasion in the $13^{\text {th }}-14^{\text {th }}$ centuries, despite the periods of confusion and wars, the Galician-Volhynian Principality lived more balanced and calmer in

\footnotetext{
${ }^{2}$ Ibid. C. 16-17.
} 
general than the Dnieper Ukraine in $11^{\text {th }}-12^{\text {th }}$ centuries. Due to the favorable location of the Galician-Volhynian lands, specifically on important transit routes between East and West, the export of salt, grains, amber contributed to the development of the economy, international and regional trade relations. At the same time, it was a factor of a certain political and economic stability, the development of culture. Even in the last quarter of the $14^{\text {th }}$ century, GalicianRuthenian half-grosz was widespread not only in the Galician land, but also in Volhynia, Kyiv, Poland, and Moldova.

The key to the development of Ukrainian music on the territory of this Principality was also the fact that after the Mongol-Tatar invasion, when Kyiv and the Dnieper region fell, clergymen, merchants, industrialists, artists and writers left it. Some emigrated to northern Suzdal, while others moved to the west, where the Galician-Volhynian state rose to power. It continued the great-power aspirations of Kyiv for another century and became a safe place for cultural creative work.

Thanks to creating conditions for the development of nationalities in SouthWestern Rus and becoming a political and cultural center of gravity for some time, the Galician-Volhynian Principality even experienced the flourishing of urban culture. In particular, this was facilitated by the fact that castles with fortifications were built in many cities in the $13^{\text {th }}$ century. Later, the medieval cities of the Galician-Volhynian state crystallized into multifaceted social organisms. The largest of them were already multinational. Colonies of foreign merchants, namely, Armenians, Germans, Poles, Tatars, and Jews, settled here. Already in the $14^{\text {th }}$ century, there were more than ten Orthodox churches, three Armenian, and two Catholic churches in Lviv. These were favorable conditions for the interaction of eastern and western elements, and the process of their synthesis began. Unfortunately, it was interrupted by a cataclysm - the loss of its own statehood and the division of lands between the Kingdom of Poland and the Grand Duchy of Lithuania (GDL) ${ }^{3}$.

When presenting the cornerstones of the Ukrainian culture of the Princely times, it is noted that it was based on local, folk elements in the first place. Such components were manifested in beliefs and folk philosophy, abundant daily life and lore, various genres of art. The active functioning of various genres of calendar-based ceremonial musical and poetic activity in the times of the Galician-Volhynian Principality is proved by the presence of its fragments in the chronicles in the form of legends, fragments of songs, single poetic phrases, funeral keening, etc.

We consider the fact that the Galician-Volhynian Principality united only ethnographic Ukrainian lands to be the argument in favor of the fact that the period of the $13^{\text {th }}-14^{\text {th }}$ centuries was an important stage in the formation of national music. Therefore, the features of Ukrainian culture as the basis of

${ }^{3}$ Ibid. C. 20. 
national individuality became more pronounced here. Given the interdependence of rhythm and melody in ancient songs, music, speech and its intonations, an important proof of its ethnic development in this period can be a clear difference between the language and character of the GalicianVolhynian chronicle, a unique work of ancient Ukrainian literature and historiography, from the chronicles of Suzdal. It has already clearly shown the developing features of the language of the Ukrainian ethnic group. Manuscripts of the $13^{\text {th }}$ century also have distinct Ukrainian linguistic features. This process intensified, and although in the $14^{\text {th }}$ century, a large number of works of Ukrainian writing were created in the Church Slavonic language like works of the previous period, a significant number of popular Ukrainian words and forms can be already found here.

At the same time, there have been identified certain types of historical and ethnographic zoning of the most extensive Galician-Volhynian territory, which had different climatic zones, their own history of development, different types of household production, different forms of communication, etc. In the $12^{\text {th }}-14^{\text {th }}$ centuries, Volodymyr, Lutsk, Dorogobuzko-Peresopnytsia, Bolokhiv, Brest, Kholm, Cherven, Belz, Przemyśl, Zvenygorod, Terebovel, and Halych regions are distinguished here. At the approximately same time, the following main regions are distinguished on the territory of the Upper and Middle Naddnistrianshchyna: Galician land, Ponyzzia (Podillia). In the first one, some ethnographic separate groups have gradually crystallized over time: Boikivshchyna, Hutsulshchyna, Pokuttia, and Opillia. According to ethnomusicologists, the south-western region is the most heterogeneous in terms of historical and ethnographic, linguistic, colloquial characteristics - Bukovyna, Prykarpattia, the Carpathians, and Volhynia. At the same time, they note the specificity of culture and daily life of the population of similar regions of Ukraine, which had their own special laws, customs and ceremonies, ancient musical instruments, etc. That is, on a single genetic, historical, and ethnographic basis of Ukraine (common origin, unity of ethnic self-identification and common self-description, etc.), there were touches of regional identity even at that time. It is no coincidence that ethnomusicologists note differences in the song repertoire and its character in the Ukrainian ethnographic field. Such features are observed almost in parallel with dialectical differences. Moreover, the existence of musical dialects has now been proven. Such differences in folk songs could have manifested already in the days of the Galician-Volhynian Principality. After all, the very first manifestations of the distinction of linguistic and territorial, regional units can be dated to the $5^{\text {th }}-6^{\text {th }}$ centuries. Simultaneously with the crystallization of the single old Ukrainian language, the speech patterns of large regions of the Galician-Volhynian state itself could become more and more apparent, especially in the $14^{\text {th }}$ century. 
All this gives grounds to assert the existence of regional features of folk songs, in which speech differences could not fail to manifest themselves at that time. After all, folk melos is a musical stream of consonance, a diverse multicriteria phenomenon. It involves diapason, rhythmic, harmonic, timbre, agogic features. A characteristic feature of the melos of folk songs is that it develops inseparably from the word, does not appear outside it, and coincides with the latter in the formation of the logical integrity of the song.

Since the rural population is the main guardian of traditions, their carrier, and in the $12^{\text {th }}-13^{\text {th }}$ centuries, strong church communities have not yet been established in all regions of Volhynia and Galicia (as in the rest of Europe, the process of Christianization took place gradually), there are reasons to consider pagan ritual songs to be part of the musical culture of the Galician-Volhynian state, especially in its early days. This is confirmed by the conclusions of archaeologists regarding the coexistence of pagan shrines and Christianity in Galician Rus until the middle of the $13^{\text {th }}$ century. Today, we know of pagan sanctuaries of complex structure and large religious pagan centers, for example, on Zbruch, in the Carpathians. Under the guidance of professional priests, complex ritual actions were performed. Only later, in the crucial Lithuanian-Polish times, in the $14^{\text {th }}-16^{\text {th }}$ centuries, the Christian rite and worship, the cohort of clergy and its influence spread among the masses. Over time, the main pagan rites were adapted to the church calendar (their koliadkas were timed to Christmas, spring songs to Easter, mermaid songs to the Pentecost, Kupala songs to St. John's Day). Thus, the strata of pagan singing lost its cult purpose, was gradually enriched with new historical content, and moved into the folklore sphere.

Some interaction in song folklore took place between Ukrainians and Armenians, Jews, Ugrians, Vlachs, Tatars, and later Poles and Germans who settled in the Galician-Volhynian Principality ${ }^{4}$.

Awareness of existence of circumstances in the social and economic, cultural and church life of the $13^{\text {th }}-14^{\text {th }}$ centuries that contributed to the preservation of the old druzhina tradition helps to see the place of music in the life of Ukrainians better. At the same time, its development ranged from lyrical to epic component. Potential impulses to create epic musical and poetic compositions could arise during downtime after the battle, in the field, when returning with recent impressions of the event.

Bylynas (epic poems) were an important component of the musical culture of the Galician-Volhynian Principality. Their origins are associated with Kyivan Rus, where the epic tradition was highly developed. As the leading genre of ancient national epics, they complete their formation in the late Middle Ages. The bylyna epics were performed by special singers accompanied by the string instrument called gusli, later kobza. Not only the

${ }^{4}$ Ibid. C. $21-36$. 
exploits of Princes, boyars, druzhina warriors, and other folk heroes were sung in a recitative and melodic form, stories of grand and heroic content, they also depicted Princely life, customs, song and music realia, and so on. These works are part of the great epic tradition of the East and the North and are its boundary. In the $13^{\text {th }}-14^{\text {th }}$ centuries, bylyna epics are filled with new storylines related to the realities of the Galician-Volhynian state: about Prince Roman, Duka, Churylo Plenkovych, Mykhailo Kozaryn, and others. Gradually, the bylyna is transformed into folk genres, including ballads. The final glorifying episodes of the bylynas pass into dumas ${ }^{5}$.

The study of the significant heritage of Ukrainian historical songs allowed ethnologists not only to reconsider outdated ideas about the reasons for the emergence of this folk genre, but also to establish that these works did not appear in the $15^{\text {th }}-16^{\text {th }}$ centuries, but one and a half or two hundred years earlier in Zakarpattia( the indigenous Ukrainian population was the first to fall victim to the aggression of foreign occupants) and in the ethnographic Ukrainian lands of Eastern Slovakia - Prešov region.

As for the art of other ethnic groups living in Ukraine, researchers even suggest the existence of recitative knightly songs in secular Armenian music.

In addition to bylynas, the heroic epic of the Galician-Volhynian lands includes some koliadkas and shchedrivkas (Christmas carols). In terms of content, nature and purpose, the latter are determined by panegyric and congratulatory New Year's greetings. As a component of Christmas carols, shchedrivkas are a kind of addition to koliadkas. Koliadkas and shchedrivkas were changing, losing their original magical character and purpose, were replenished with new motives and, while becoming congratulatory wellwishing songs, usually reflected not only the lives and hopes of people of later times, but also historical events in generalized form.

The chronicle mentions the Polovtsian singer Or, who worked in Princely Kyiv. We believe that this musician could perform his works accompanied by such a common at that time string instrument as a hudok. We also consider its use on the territory of Galician-Volhynian Rus.

Close to epic genres are songs of praise, which were a special glorifying singing with heroic and patriotic content during the Princely era. Their origins can be seen in the Byzantine acclamations. Songs of praise have survived to our time both in oral folklore (koliadkas, shchedrivkas, songs of praide, epics) and in written sources (especially chronicles, as well as church hagiographies). The chronicle mentioned is rich in references to songs of praise. As a special kind of glorifying singing, they contributed to the assimilation of Byzantine hymnography by the Kyivan state in its local national forms, because there was much in common, both in image and

\footnotetext{
5 Ю. Ясіновський. Пісенний фольклор і музичне мистецтво. Історія української культури: у 5-ти томах, т. 2: Українська культура XIII-першої половини XVII століть / [редкол. тому Я. Ісаєвич (гол. ред.), Ю. Ясіновський, Л. Войтович та інші]. Київ, 2001. С. 328-329.
} 
thematic, and in musical and expressive aspects ${ }^{6}$. At the same time, fragments of various songs are intertwined in the Galician-Volhynian chronicle: historical, druzhina-related, monastic, princely, artisan.

A special place in the artistic and aesthetic life of the people of Princely times was occupied by skomorokhs - traveling musicians (singers who also played the hudok, gusli, other musical instruments), dancers, storytellers, play actors, tamers. They gradually stood out from among those who possessed the art of playing musical instruments, had considerable practice, and gradually evolved from amateur musicians to professionals who performed for a fee. They were the bearers of new musical ideas. The settled way of life of folk musicians is evidenced by the toponymic names formed from the stem skomorokh. To this day, there are many names of settlements such as Skomorokhy, Skomoroshky in Ukraine, in particular, in Galicia and Podillia.

Back in the $13^{\text {th }}-14^{\text {th }}$ centuries, the tradition of traveling musicians remained active, which, in the end, was characteristic of the whole of Europe. Skomorokhs, Spielmans, Meissgersingers, and vagrants traveled throughout the European continent and were the main bearers of the international song and dance repertoire. Ukrainian musicians, who could often be seen at the courts of Polish and Hungarian kings, nobles, and magnates, as well as the city patricians, also joined this process. Our compatriots brought the Ukrainian repertoire to the West with them, which took a certain place in the lute and organ tablatures. Evidence of the remarkable skill of Ukrainian musicians was that they appeared in the $14^{\text {th }}$ century in the service of the chapels of Polish kings and magnates.

The repertoire of Princely and druzhina singers passed to the skomorokhs (a similar thing happened later with the Cossack dumas: they were adopted from the Cossacks by traveling kobzars-bandurists or singers of spiritual songs - lirnyks). That is, the heirs of skomorokhs in the Carpathians were trinity musicians - professional artists of the newer type, who replaced the ancient gusli and panpipes, and used the violin, tsymbaly and bell tambourine and played at weddings and other village parties. The skomorokhs are well reminiscent of groups of Ukrainian carolers and Belarusian volochebnyks ${ }^{7}$.

But this is only one of the lines of development of instrumental music, the folk one, the specific stages of which are difficult to establish. Another one is related to the $14^{\text {th }}-15^{\text {th }}$ centuries, when from the time of the Lithuanian-Rus state, and later the Polish-Lithuanian kingdom, the shoots of the humanistic culture of the European Renaissance pierced out in the Galician-Volhynian lands. Then new social conditions for the development of Ukrainian musical professionalism were formed at that time. It was clearly reoriented from the medieval church and monastery environment to the urban secular culture.

${ }^{6}$ Ibid. C. $330-332$.

${ }^{7}$ Б. Кіндратюк. Нариси музичного мистеитвва Галицько-Волинського князівства. С. 47-51. 
Cities became the centers of development of musical art with their characteristic institutes: guilds, fraternities, schools, magistrates, cathedrals, and parish churches. Therefore, the social status of a professional artist changed, since he became a secular freelancer: singer, cantor, regent, teacher, author or editor of church songs, magistrate trumpeter, bell ringer, guild musician, and so on. This prompted such artists to react quickly to musical and stylistic changes, and in folk music - to fashion, people's requests, various musical novelties (popular songs, dances). When rewriting Irmoloy's musical notes at the request of the church, school, and individual citizens, they tried to preserve the local singing tradition and simultaneously make certain musical and stylistic innovations in the spirit of the time. As we can see, musicians have developed the professional psychology ${ }^{8}$.

\section{Church music}

The specificity of the culture of Galician-Volhynian Rus was determined primarily by the adoption of Christianity from Byzantium. At present, there is little information about the ways of its spread on different territories, so it is difficult to determine the exact time of establishment of the parish network in the Galician-Volhynian lands. Studies on the spread Christianity of Cyril and Methodius direction in Prykarpattia and Cherven Grods give some researchers reason to speak more confidently about the founding Przemyśl Diocese ( $9^{\text {th }}$ century) along with Tmutarakan one ( $8^{\text {th }}$ century).

The spread of liturgical literature necessary for church services was the key to the rapid progress of spiritual creative works in the region. If in the $11^{\text {th }}$ century an important role in the history of Ukrainian literature belonged to the Kyiv Grand Ducal Scriptorium, thanks to which liturgical literature spread in Galician Rus, then in the $12^{\text {th }}$ century, ancient Halych was of great importance in the development of the written word, and in the second half of the $13^{\text {th }}$ century, the need to compensate for the losses in book production suffered by the southern and southwestern lands of Ukraine as a result of the devastating Mongol-Tatar invasion, and to provide rebuilt and newly built churches with liturgical literature led to a powerful production of manuscripts in Volhynia and Bukovyna. The cities of Volodymyr, Kholm, and Przemyśl were also significant centers of book writing in Galician-Volhynian Rus. The emergence of new regional places of book writing was an achievement of the $12^{\text {th }}$ century. They were destined to play a leading role in the cultural development of the region in the next, difficult for Rus century.

Active book writing in the Galician-Volhynian state was the key to the fact that in the $14^{\text {th }}-15^{\text {th }}$ centuries, a formal language common for Ukrainians and Belarusians was formed based on East Slavic, which was nourished by folk sources. Both at this time and later, it was recognized as the official language

${ }^{8}$ Ю. Ясіновський. Пісенний фольклор і музичне мистецтво. С. 333. 
of the Grand Duchy of Lithuania, used in administrative and legal documents, public administration in Poland and the Principality of Moldova. At the same time, it could contribute to the distribution of handwritten notated liturgical books.

The main genre of professional music of the Galician-Volhynian Principality was canonized church singing - sacred monody (hymnography) a special kind of musical and poetic art in a solo voice musical notation. Together with architecture and painting, they symbolically generalized religious consciousness and the Christian faith in their inherent art forms. Hymnography was an important component of worship, bringing emotional coloring to the ritual Christian forms. On the Ruthenian Ukrainian basis, Byzantine church songs were intertwined with local praise song genres. Even in the Princely era, there was its own musical-poetic style, which became the first stage of formation of national professional notated music.

One of the keys to the development of sacred singing in GalicianVolhynian Rus was that its rulers strengthened the Church, primarily by providing land holdings. This was also facilitated by the construction of new temples and monasteries. It is known about the significant spread of wooden churches of various types and shapes on the Galician land in the $12^{\text {th }}-$ first half of the $13^{\text {th }}$ century. In large cities, sacred buildings were usually made of brick. These were the places where books with liturgical songs were rewritten, professional choirs were housed, children and young people music were taught music.

In the Galician-Volhynian state, perhaps for the first time in Eastern Europe, early forms of polyphony appeared. There are hypotheses about possible contacts with the most influential Western school of early polyphony - the Parisian Notre Dame of the $12^{\text {th }}-13^{\text {th }}$ centuries. Instead, cult monody reigned in the few Catholic and Armenian churches and Jewish synagogues in the Principality.

The expansion of the network of parish churches led to the creation of Irmoloy's - collections of festive and most glorifying songs. The direction in the development of Ukrainian culture and art of the $14^{\text {th }}$ century, associated with the rise of Western culture in the Renaissance, is called one of the reasons for the emergence of a new type of hymnographic compilation. This also created new social and historical conditions in the Galician-Volhynian Principality, where the city became the center of culture, and not the church and monastery environment ${ }^{9}$.

An important source of information about music, in particular, church singing, is iconography. Please recall the icon Pokrov Bohorodytsi (Protection of the Mother of God, from the church in Malnov) of the $12^{\text {th }}-13^{\text {th }}$ centuries with unique features in terms of iconography and style, which indicates the

${ }^{9}$ Ibid. C. 332. 
development of the relevant direction of painting of the Princely era. Such icons traditionally depict the moment when, according to legend, Roman Sladkopivets received the gift of composing kontakions and singing in a dream, woke up, went to the pulpit and while holding a scroll with the words of the kontakion written on it sang it in honor of the Nativity of Christ: «Діва днесь Пресущественного рождаєт!». Here, the work of a prominent Syrian deacon is considered a gift of revelation, Sladkopiovets. When performing kontakion, people picked up his chorus. The iconography of the Pokrov is also interesting in that it is almost the only image of kontakion singing. The depiction of the then church and musical reality, in particular the singers in hats - skiadia and skaranikon is also of interest ${ }^{10}$.

Priests, deacons, and cantors took care of the observance of the established order of church singing and preservation of their purity. Adherence to the canons of church singing, bell-ringing, etc. required specially trained attendants, and hence their musical and professional training. Regarding sacred music and the importance of the role of the cantor in it, we would like to add that he responds to the priest during the service by singing. The social significance of cantors in ancient times is also explained by the fact that due to their education they sometimes worked in the Prince's offices or headed them, i.e. performed the governmental functions of chancellor (deacon or typographer). Details about one of them are written in the chronicle under 1219, which tells of the battle of Polish soldiers and Hungarian troops with an army of Galicians near Horodok. This detail testifies to the fact that the cantors took part in the battles (probably to establish the spiritual singing of the soldiers - to strengthen their courage), and the importance of the clergy in life ${ }^{11}$.

There is am opportunity to rethink the usual image of the chronicle of Mytuda nowadays. The functions of this musician were usually interpreted one-sidedly. He was considered either as a singer or simply as a church singer. However, when studying the source base and relying on the study of researchers of the role and place of musicians in the art of the ancient Kyivan state, it is reasonable to assume that the role of the "slovutnyi" Mytusa in chronicles, who refused to "serve Prince Danylo", like others similar to him at the time, was much more significant (remember at least the prophetic Boyan from the ancient Ruthenian poem The Tale of Igor's Campaign). Since archaic elements clearly appear in art, in the images of songwriters, guardians of early ritual poetry as well as vocal and musical genres, their mythopoetic songwriting was likened to the functions of a priest who fought the chaos. Since singers appear as "mages"-soothsayers, sorcerers of "spells", their winged commissioned word was attributed a powerful force. Therefore, it was believed that musical and poetic creative works can do miracles

\footnotetext{
${ }^{10}$ Б. Кіндратюк. Нариси музичного мистецฺтва Галицьько-Волинського князівства. С. 96-99.

${ }^{11}$ Ibid. C. 66.
} 
Given this role of the musician-soothsayer (prognostic function), Mytusa's behavior becomes clearer and his authority in the spiritual life of that time is better understood. Since the singer was perceived as a magician in the popular consciousness, the Church of the Galician-Volhynian state also wanted to have such individuals in the service in order to spread its influence. And the fact that Mytusa could be a pagan priest suggests the already mentioned simultaneous widespread existence of pagan shrines and Christianity here until the middle of the $13^{\text {th }}$ century. As we know, pagan rituals organically included melody, speech, and movement. At the same time, the magic of calendar-based ceremonial songs enchanted the good and evil forces of nature. These works were a kind of folk prayers to it, to various deities. Similarly, the custom of poetry and song art emerged in the early Christian communities. Not surprisingly, sacred singing is one of the determining means of a powerful influence of the liturgy on parishioners in the synthesis of temple rites, along with reading the Holy Scripture, church painting, some types of stage activity, canonical bell-ringing, etc. Accordingly, the dominant role was played by a person who not only stood out with the knowledge of all rituals, but also created them, attracted attention as a performer. They were distinguished by musical abilities, in particular, vocal abilities, i.e. it was a priest, church priest or cantor. Maybe that is why such musically gifted people as Mytusa from chronicles were called "slovutnyi". It is legitimate to speculate that he could have performed different social roles in a certain sequence or simultaneously during his life at the same time ${ }^{12}$.

The adoption of Christianity and the spread of written culture led to the development of several new literary and artistic genres in Ruthenian Ukraine. The church rite called for appropriate forms of worship, filling them with appropriate means, among which an important role belongs to the regulated use of semantrons, bells and bell-ringing.

Using the bells and the strengthening of the custom of bell-ringing were brought to Ruthenian Ukraine together with the Christian rite, but not from Byzantium, where bells were not common, but from the Latin West. They came to Galician-Volhynian Rus from Kyiv or from the Germans through the Poles. The significance of this church attribute at that time is evidenced by the fact that the bells were an important military trophy, which was repeatedly mentioned by chroniclers among the list of loot taken out, in particular, from Kyiv.

The state-building processes in the Galician-Volhynian Principality prompted Danylo of Galicia to take active action, first of all, to strengthen the Church. In order to spread Christianity, he not only ordered to construction of new temples and the restoration of destroyed ones, but he also helped to decorate them with icons, books, and equip them with bells in order to enhance the significance of the liturgical rite.

${ }^{12}$ Ibid. C. 67-78. 
In ancient times, bells were of great importance in public life: they called parishioners to worship, were used in its most solemn moments. The bell also announced death and sounded at funerals, united the people during natural and social disasters, convened a meeting, called for defense. The victories of the Prince's druzhina were celebrated with bell-ringing as well. From ancient times the bells, the bell-ringing were perceived as a ritualistic, solemn, glorifying act. We learn about other essential information about the functions of bell-ringing, its prevalence, volume and metaphorical symbolism, etc. from church Charters, various written sources, especially chronicles.

From ancient times there was a need for a large number of bells, which are commonly expensive percussion musical instruments from the group of idiophones. The Zvenygorods from chronicles, of which there are many, can be considered as a peculiar echo of the filling of Galician-Volhynians "grods" and villages with music, in particular, bell-ringing.

The significant need for bells contributed to their direct casting in our region. The basis of the casting of bells in the Galician-Volhynian lands was a close connection with the foundry culture of Kyivan Rus, especially when they became a talisman for refugees from the Mongol-Tatar invasion. In addition to artisans from the eastern principalities, foreign craftsmen have also played a significant role.

This laid the foundations for the production of bells for church and secular purposes on the territory of our region. This is confirmed by another mention of these musical instruments in the chronicle. After the death of Prince Volodymyr Vasylkovych ( $\dagger$ 1288), it is recalled that he «поліа жє и колоколы дивны слышаніємь, такыхъ жє нє бысть въ всєй зємли». And this is not accidental, because artistic creativity in Volhynia, Galicia and Kholmshchyna in post-Mongol times was diverse and fruitful.

The development of bell-ringing in the Galician-Volhynian Principality is evidenced, in addition to archaeological monuments and documentary sources, by a unique bell of 1341 in Lviv St. George's Cathedral, the only completely preserved to this day in Ukraine. This idiophone, made by the Ukrainian master Yakov Skora, is qualitatively cast, made with good proportions. On the crown of the bell there is an embossed inscription: $« \mathrm{~B} b$ льто 6849 сольянъ бысть колоколь сиі святому Юрью при князи Дмитриі игуменом Свьфимьемъ» ("This bell was cast for St. George during the reign of Prince Dmytro for Hegumen Euthymius"). The latter was the third hegumen of St. George's Monastery, and Dmytro, apparently, is the Lithuanian prince Demetrius of Liubar. It is symptomatic that there were many innovations in the life of Rus during his reign. It is believed that the bell could have been cast in honor of Lviv's accession to the Lithuanian state (over time, it was, in fact, the Belarusian-Lithuanian-Ukrainian state - GDL). Neither wars, nor fires, nor inter-confessional disputes have destroyed this 
oldest of the largest bells in Ukraine, which is still used with even bigger and five smaller ones ${ }^{13}$.

An important indicator of the remarkable development of education in the Galician-Volhynian principality at that time is the significant spread of writing among various segments of the population. For example, archaeologists have discovered many different artifacts of epigraphy and sphragistics, bronze and iron pens. The latter are found not only in large cities but also in small settlements. Confirmation of the prevalence of literacy are also clasps from manuscripts, birch bark letters found.

It is not yet definitively established what the system of music education was in the Galician-Volhynian Principality. If we take into account the successful spread of literature here in the late $10^{\text {th }}-11^{\text {th }}$ centuries, which are explained, in particular, by the broadest strata understanding the Church Slavonic language, we assume a certain musical awareness of readers of the Old and New Testaments. From its pages, we learn not only how to sing or what songs to perform, but also what instruments they played and how they sounded.

The popularity of the Psalter and its long-standing distribution in manuscripts is confirmed the unique artifact of the $14^{\text {th }}$ century - the facsimile edition of the Lutsk Psalter of 1384, transcribed by the priest John in the Lutsk monastery of St. Catherine. The manuscript is now in the Biblioteca Medicea Laurenziana (Florence).

An important guarantee of the development of musical culture in those days was not only teaching children to sing, but also to play various musical instruments. The beginning of this process could be musical toys - flutes, clay whistles in the form of a horse or a bird, buzzers and rattles (multi-colored ceramic eggs glazed and hollow inside with drawings; there is a ball that turns them into a percussion musical instrument and toy). Similar items of our production were among the items of ancient Ruthenian exports ${ }^{14}$.

An important component of musical education in princely times was the activity of cantors. Since they are often mentioned in written records of that time, there is a need to show the role of this position in education, including music. After all, cantors in ancient times, while performing their church duties, taught children to read and write (cantors-teachers). After all, educational institutions also existed at episcopal cathedrals, large churches, and monasteries; the teachers here were priests and cantors. In focusing today on the importance of the Church of princely times in the development of culture, in particular education, we note the importance of the role played here by deacons (cantors) as music teachers. It is also exacerbated by the fact that monasteries and churches had scriptoriums - libraries, which stored notated liturgical literature.

\footnotetext{
${ }^{13}$ Ibid. C. 79-94.

${ }^{14}$ Ibid. C. $95-104$.
} 
If the liturgical books, most often the Psalters, as well as the notated Octoichus and Irmologion served as textbooks at that time, and church singing was an integral part of education, we can assume that the students not only sang by ear following the teaching cantor, but also got acquainted with musical notation and learned to reproduce the songs necessary in the liturgical music with its help. After all, cantors as leaders of church choirs had to take care of the addition of qualitative new singers. Icon-painting played an important role in their preparation among the subject means of education. At the same time, the development of various genres of art was conditioned and determined by the progress of education at that time.

\section{Instrumental culture, music in everyday life and the army}

Natural, geographical, and social conditions of each ethnographic region contributed to the development and preservation of many original musical instruments. The type of economic management is considered as an important factor in the formation of the features of instrumental culture. There is no unified Ukrainian folk instrument, but there are Boyko, Hutsul, Polissia ones, etc., because the people of each region of Ukraine understand this or that instrument in their own way. At the same time, one of the first reasons for local construction and performance features, in particular in the GalicianVolhynian lands, is also the choice of different materials used in the creation of even the same musical instruments.

As ethno-instrumentalists rightly claim, prototypes of artistic tools reach the depths of millennia. After all, such musical instruments as horn, trembita, tylynka, drymba (jaw harp), rebro (syrinx), various hunting vabkas (i.e., duck calls), ceramic and wooden (mostly zoomorphic) whistles in the form of a cuckoo, a rooster, a horse, etc. have reached us without any significant changes, as well as a large number of percussion self-sounding instruments (sematrons, clappers, derkachs, mallets, bells, rustles, rattles, etc. various in design and function). There was also archaic "playing" of a leaf grass or wood, birch bark; whistling "into fingers", "into the tongue", in a hollow nut, an acacia pod, an acorn cap, etc. Carrying elements of primitive culture, shrouded in legends and beliefs, these amazing creations of folk genius still function in the cultural life of Hutsuls, for example ${ }^{15}$.

Thus, there was a significant number of musical instruments in the GalicianVolhynian area of Ruthenian Ukraine. Like everywhere else, they emerged as a result of economic and labor activity of man as a need of his artistic selfexpression. At the same time, their list expanded due to borrowing. During this period, the scope of instrumental music has significantly expanded - at the princely and boyar courts, the army, in the urban environment. Some of the functions of musicians and the reasons for the need for a large number of

\footnotetext{
${ }^{15}$ Ibid. C. 105-107.
} 
performers stem from the reasoning of historians regarding the plausible presence of the nobles to have a large number of professional singers in the courts. Their works were adopted and multiplied by their variants, popularized, made more accessible to a wide range of people.

The era of the Crusades contributed to the development of musical and instrumental culture in the $14^{\text {th }}$ century in Eastern Europe. Thanks to them, foreign ways of singing and playing spread. During their travels, the knights learned about other countries, customs and traditions, which was one of the impulses for creative activity in courts.

The instrumental music in the Galician-Volhynian Principality was changing gradually and significantly. The Eastern Scythian-Sarmatian type of instruments and forms of music were narrowing. The fall of ancient Eastern civilizations slowed down and eventually halted the long process of influx of Eastern instruments into Princely Ukraine, its forms of existence and repertoire.

It is in the Galician-Volhynian Principality that cultural ties with Western Europe are strengthening. This also influenced the formation of a new type of instrumental culture, although it is absolutely clear that in the $13^{\text {th }}-14^{\text {th }}$ centuries, Western Europe itself was still very young in terms of secular instrumental music and was undergoing a stage of active assimilation of Eastern instruments and forms of music, mainly from the Arab-Muslim world. The Galician-Volhynian lands were a stage on the way of the use of musical instruments moving from East to West. After all, playing instruments was quite developed in the Middle East at the end of the first millennium AD. From there, the culture of using musical instruments permeated Western Europe. Among the ways of this penetration were not only Spain, Italy, the Balkans, but also Ukraine. Other finds of archaeologists convincingly testify to the significant spread of various musical instruments in the GalicianVolhynian state ${ }^{16}$.

Thus, various sources testify to the existence of various musical instruments: idiophones (sematrons, bells, metal plates, glockenspiel), membranophones (tambourines, jingle bells, bell tambourines), chordophones (hudoks, guslis, lutes, rebecs), aerophones (sopilkas, trumpets, "trembitas", "flutes", various whistles) in the Galician-Volhynian lands.

Military music. Musical art occupied a special place in the Prince's druzhinas. Trumpets, tambourines, and surma-horns (wooden pipes) were necessary accessories for the army. Musicians played an important role in the management of combat operations. Military musicians also signaled the march with surmas and trumpets. Trumpeters sometimes called the enemy into battle. Based on the study of historical artifacts, researchers claim that the number of surmas and tambourines could lead to a conclusion about the size

${ }^{16}$ Ю. Ясіновський. Пісенний фольклор і музичне мистецтво. С. 325-328. 
of the division of the regiments. Thanks to combining military musicians into "orchestras", their sound was not only an encouraging and stimulating factor to influence their own people, but also a means of intimidating the enemy the roar of surmas, trumpets and the sound of tambourines was to frighten the enemy. The musicians took part in the celebration of victories.

The significant spread of Greek church singing in the music of Kyivan Rus in the $12^{\text {th }}$ century was caused by the daily performance by the townspeople and druzhina of Kyrie Eleison (translated - Lord, have mercy upon us!). Such singing, respectively, was performed by Christian soldiers when they went into battle. One of the peculiarities of Danylo of Galicia's army was the transformation of the people's militia from peasants into powerful infantry units, so in this part of the armed forces, there could be some differences in military music, in particular a kind of group singing - it was closer to folk songs. It was this military union that required the considerable attention of priests and cantors. They, as we know from the chronicle, also took part in the fighting. That is, there could be certain differences in this area of musical art of the Galician-Volhynian state.

Ceremonial music. Another type of traditional music professionalism of that time is called ceremonial music. "Salute" using trumpets was played in the Kyivan state on various solemn occasions - at the conclusion of peace treaties, meetings of ambassadors, return of troops from the campaign, etc. One of the miniatures of the Kyiv illustrated chronicle refers to the events in Princely Halych. Here the young prince Yaroslav is depicted on a throne, in a crown and a cloak. He gestures to a group of boyars lo leave. On the left, there is a swordsman with a bared sword and a trumpet player. It is believed that this trembitar announces the death of Prince Volodymyrko.

Music on the hunt. The factor of its development was the use of musical instruments on the hunt. Among their types, there are those which have long been used to imitate the singing of birds or the cries of animals. This way they attracted game animals on the hunt, which was an important type of business at the time. The sounds of trumpets and horns were controlled by hunters. This makes it possible to assume the existence of special signal music.

Musical art is a component of princely and druzhina ceremonies and feasts. They were arranged in honor of someone or the celebration of an event and so on. Researchers of the prince's court in Terebovlia found houses in which sacrificial feasts were held. According to archaeologists, the Prince's court of ancient Halych could also have had a more spacious "hrydnytsia", where the Prince's lifeguard was housed in the first place, and large feasts were held for numerous guests. Such feasts are often mentioned in the pages of the chronicle. Skomorokh could be invited to cheer the guests. During the feasts, songs of praise, works of heroic epic, etc. were performed. There they could sing zazdravni chashi, absolution poems. At such meetings, interethnic 
exchange of achievements in the field of music could take place. After all, the reception of foreign guests provided for the organization of feasts, which they sometimes attended with their musicians ${ }^{17}$.

\section{CONCLUSIONS}

The study of archeological materials and chronicles, paintings, achievements of ethnography, historical linguistics, etc. allowed to draw many valuable insights about the significant role of music in the lives of people of Galician-Volhynian lands and a remarkable level of development of this genre of art. This was facilitated by social and economic development, which created conditions for the continuation and flourishing of the spiritual traditions of Kyivan Rus. The connection with the national roots of folk genres, in particular the musical culture being based on local pre-Christian syncretic rituals, mutual enrichment of art of different ethnic groups, etc. became the basis for further progress of Ukrainian music, its ethnogenesis on the territory of the Galician-Volhynian state (Kingdom of Rus). At the time of its formation, there was an intensive strengthening of the Church, the continuing development of hymnography, its saturation with local verbal and musical features. At the same time, the conversion of the broad masses to Christianity contributed to the enrichment of the calendar-based and ritual folklore with new themes. It was during this period that Ukrainian bylynas and historical songs were born. A significant part of them appeared and was dedicated to events on the territory of the Galician-Volhynian Rus.

Here, the well-spread book-writing contributed to the spread of liturgical literature within the state and on the adjacent territories. Together with local editions of church law, the notated books created the preconditions for the process of adaptation of Byzantine-Bulgarian songs on Ukrainian basis.

Church music of the Princely era is directly or indirectly connected with sacred monumental, easel and book painting. In turn, they are integrated by means of words. Due to the affiliation of painting and music to the Church, they played a leading role in art, as they had the opportunity to develop as professional spheres (training, continuity of traditions, musical notation, etc.). The development of various genres of art was defined and determined by the then progress of literature and education, including music-related one.

The music of the Princely era was not just an important component of the church rite, but an indispensable means of socialization of the individuals, their education and training. The development of people's musical education was facilitated by the collective performance of church hymns, the reading of the Old and New Testaments, as an ancient respectable means of disseminating musical information and the educational foundations of their acquisition. This was also facilitated by acquaintance with icon painting and so on.

${ }^{17}$ Б. Кіндратюк. Нариси музичного мистеитва Галицько-Волинського князівства. С. 105-131. 
In the Galician-Volhynian Principality, the sphere of instrumental music making has considerably expanded. Musical instruments were distributed not only at Princely courts or in the urban environment in general, but also in rural life, among ordinary people. Due to this, professional musicians were formed, musical instruments were improved, new genres were born. As a result, the art of music acquired a national, in particular ethno-regional coloring.

Traditional forms of professionalism (church music, military and ceremonial music, song epics, entertainment and household genres, etc.), professional training and written fixation (notation) of sacred songs were a prerequisite for integrating the ancient Ukrainian musical culture of GalicianVolhynian Rus into the world art process.

Continuation of research of archeological findings, manuscript sources, paintings, etc. of this region of Ukraine will contribute to a fuller systematization of our ideas about its music, will help a deeper scientific understanding of the development of musical art of the Galician-Volhynian Principality as one of the stages of genesis and formation of Ukrainian music.

\section{SUMMARY}

Systematization of materials about the musical art of the GalicianVolhynian Principality, folk art considered, instrumental culture, musical everyday life of the prince's court and city, church singing, art of bell-ringing showed that music of this time is an important but little studied historical stage. It ensured the development of Ukrainian music after the fall of the Kyivan state.

\section{REFERENCES}

1. Кіндратюк Б. Нариси музичного мистецтва Галицько-Волинського князівства / [ред. і авт. переднього слова Ю. Ясіновський]. ІваноФранківськ - Львів : Ін-т українознавства ім. Івана Крип'якевича НАН України, 2001. 144 с. (Історія української музики: Дослідження, вип. 9).

2. Ясіновський Ю. Пісенний фольклор і музичне мистецтво. Історія украӥнської культури: у 5-ти томах, т. 2: Українська культура XIIIпершої половини XVII століть / [редкол. тому Я. Ісаєвич (гол. ред.), Ю. Ясіновський, Л. Войтович та інші]. Київ : Наук. думка, 2001. C. 322-333.

\section{Information about author: Kindratiuk B. D.}

Doctor of Arts, Associate Professor, Professor at the Department of Methods of Music Education and Conducting Vasyl Stefanyk Precarpathian National University of Arts 57, Shevchenko str., 76000, Ivano-Frankivsk, Ukraine 